\title{
Estimation of Heritability and Repeatability for Pre-Weaning and Post Weaning Litter Weights of Unselected Domestic Rabbits in South Eastern Nigeria
}

\author{
Okoro V. M. O. ${ }^{1, *}$, Ogundu U. E. ${ }^{1}$, Okoli I. C. ${ }^{1}$, Anyanwu G. A. ${ }^{1}$, Chikaire $\mathbf{J}^{2}$, Raji A. O. ${ }^{3}$, Maduka C. G. ${ }^{1}$ \\ ${ }^{1}$ Department of Animal Science and Technology \\ ${ }^{2}$ Department of Agricultural Extension Technology, Federal University of Technology, Owerri. (FUTO) 2341526 Nigeria \\ ${ }^{3}$ Department of Animal Science, University of Maiduguri, 4566778, Nigeria
}

\begin{abstract}
Data from one hundred and seventy eight (178) kittens generated from 21 does mated to 7 stud bucks resulting in 34 kindling were used to estimate the heritability due to sire and repeatability for birth, weaning and post weaning litter weight traits of unselected non-descript rabbits reared in FUTO teaching and research farm. Traits such as litter weight at birth (LWB), at weaning i.e. $21 \mathrm{~d}$ (LWW), 42d (LW42), 56d (LW56) were studied. A repeatability single trait animal model was used to analyze the data Estimates of Sire heritability for LWB, LWW, LW42 and LW56 were $0.34 \pm 0.41,0.79 \pm 0.632$, $0.91 \pm 1.20$ and $0.62 \pm 0.542$ while repeatability estimate were $0.034 \pm 0.243,-0.130 \pm 0.197,0.003 \pm 0.236$ and $0.008 \pm 0.238$ respectively. These estimates indicate a moderate to high heritability while the repeatability indicates generally low estimates. This implies that selection of this non-descript population of rabbits for LWW, LW42 and LW56 could be efficient in improving these traits in the population, while the repeatability of these traits being very low, suggests that the likelihood to repeat these records is low.
\end{abstract}

Keywords Heritability, Repeatability, Weaning, Litter weight, South-Eastern Nigeria, Domestic Rabbits

\section{Introduction}

Rabbits have been found suitable for production of high quality protein to satisfy the basic needs of the rural people for protein (Fielding and Matheron, 1991). This is as a result of their early sexual maturity, efficiency at converting food into meat, short gestation period, high prolificacy and their ability to be re-bred shortly after parturition (Lebas et al, 1986). In recent times, rabbit keeping has gained ground among Nigerian households and researchers, as an alternative source of animal protein and experimental materials; and its potential in cushioning the effect of World Food Shortage has been stressed (Chen et al, 1978). Moreover, a quantitative measure for animal conformation is desirable as it will enable reliable genetic parameters for these traits to be estimated and permit inclusion in breeding programmes (Ibe, 1989). Thus, it would be possible, by selection, use of breed diversity and genetic parameter estimates, to make rapid improvement in rabbit performance (Chineke and Raheem, 2009). Litter weight at birth, weaning and other ages as it affects dam reproductive traits has been studied by many authors (El-Maghawry et al 1993, Bolet et al 1996; Peterson

* Corresponding author:

melavicong4real@yahoo.com (Okoro V. M. O)

Published online at http://journal.sapub.org/ijaf

Copyright (C) 2012 Scientific \& Academic Publishing. All Rights Reserved et al 1996; Pascual et al 1996) Although, estimates of heritability and repeatability for litter, doe and lactation traits were mostly low and have a broad range among reports (Khalil et al 1986), there is a dearth of information on the estimates for litter weight at birth, at weaning, at 42 days and 56 days in unselected non-descript rabbits of South Eastern Nigeria. The concept of heritability specifies the proportion of the total variability that is due to genetic causes, while repeatability determines the ability to repeat the expressed genotype of the individual when repeated measurements are taken on the same trait of an individual. Although information on heritability estimates of economic traits of rabbits in sub Saharan Africa is scanty, some values for litter traits had been reported (Khalil et al, 1987, Odubote and Somade 1992, Ndjon and Nwakalor 1998, Akanno and Ibe, 2005).

This study is therefore carried out to determine the estimates of heritability and repeatability for birth, weaning, $42 \mathrm{~d}$ and 56d litter weight of unselected non-descript rabbits reared in FUTO teaching and research farm.

\section{Materials and Methods}

The data used for this research was generated from the rabbitory unit of the FUTO teaching and research farm between March and August, 2006 when this study started. A total of twenty-eight parent rabbits comprising of seven stud 
bucks and twenty-one does were mated to produce a hundred and seventy eight (178) kittens from 34 kindlings. The breeding animals were generally unselected non-descript animals, comprising mainly of different colour variants and of different sizes. The does were randomly assigned to bucks at the ratio of 3:1 respectively and matings were carried out in the morning hours of 6-7am. Care was taken not to mate related individuals. Each doe was palpated 10 days thereafter to detect pregnancy. Those which failed to conceive were returned to the same mating buck at the day of test. Wooden nest boxes were provided at 27 days after fertile mating.

All the kittens were weaned at the same age (three weeks of age) and individually tagged and housed in hutches from where their body weights were taken on weekly basis. They were fed ad libitum with commercial feed (guinea feed growers mash of $15 \% \mathrm{CP}$ ) and supplemented with grasses such as Elephant grass (Pennisetum purpureum), guinea grass (panicum maximum) and butterfly pea (centrocema pubscens). Clean water was also provided regularly. Cages of all animals were cleaned and disinfected regularly before each kindling. All animals were medicated similarly and they were subjected to the same managerial and climatic conditions throughout the experimental period.

\section{Data, models of analysis and Experimental Design}

Data collected on 178 litters generated from 7 sires resulting in 34 kindling/litters (Table 1)

Table 1. Structure of the data analyzed for FUTO unselected non-descript rabbits

\begin{tabular}{cc}
\hline Source of Variation & Numbers \\
\hline Sires & 07 \\
Dams & 21 \\
Kittens & 178 \\
Litters & 34 \\
Total Number of animals in the pedigree tree & 206 \\
\hline
\end{tabular}

A nested ANOVA design procedure was used to generate the variance components due to sire, dam and error according to VARCOMP procedure of SAS (1999). This is predicated on a randomized complete block design with two main sources of variation thus

$\mathrm{Y}_{\mathrm{ijk}}=\mu+\mathrm{S}_{\mathrm{i}}+\mathrm{D}_{\mathrm{ij}}+\mathrm{E}_{\mathrm{ijk}}$

Where $\mu=$ Common mean

$\mathrm{S}_{\mathrm{i}}=$ Effect of ith Sire

$D_{i j}=$ Effect of $j$ th Doe mated to ith sire

$\mathrm{E}_{\mathrm{ijk}}=$ Uncontrolled environmental and genetic deviations attributable to individuals.

All effects were assumed normally, identically and independently distributed around equal means and zero variance.

The heritability estimates $\mathrm{h}^{2}$ was then generated using the formula according to Becker (1984):

$$
\mathrm{h}^{2}=\frac{4 \delta \mathrm{s}^{2}}{\delta \mathrm{s}^{2}+\delta \mathrm{d}^{2}+\delta \mathrm{e}^{2}}
$$

Where $\mathrm{h}^{2}=$ heritability estimate due to sire.

$\delta_{\mathrm{s}}{ }^{2}=$ Variance component due to sire

$\delta_{\mathrm{d}}^{2}=$ Variance component due to dam

$\delta_{\mathrm{e}}^{2}=$ Variance component due to error.

The variance components so generated was also used to estimate the repeatability estimate $\left(\mathrm{R}^{2}\right)$ using the formulae:

$$
\mathrm{R}^{2}=\frac{\delta \mathrm{s}^{2}+\delta \mathrm{d}^{2}}{\delta \mathrm{s}^{2}+\delta \mathrm{d}^{2}+\delta \mathrm{e}^{2}}
$$

Standard errors (S. E.) of heritability was computed according to Graybill and Robertson (1957) while S. E of repeatability was computed using the square root of the sampling variance of the intraclass correlation according to Becker (1984)

\section{Results and Discussions}

Table 2 shows the actual mean, Standard Deviation and Coefficients of Variation for Average Litter size (Av LS), LWB, LWW, LW42 and LW56 of the rabbit population.

Table 2. Least Squares Means, Standard deviation and Coefficients of variation for Average Litter size (Av LS), LWB, LWW, LW42 and LW56

\begin{tabular}{cccccc}
\hline Trait & Mean & SD & CV $(\%)$ & $\min$ & $\max$ \\
\hline AV LS & 4.07 & 1.43 & 35.16 & 1.00 & 7.00 \\
LWB $(\mathrm{kg})$ & 0.74 & 0.16 & 22.11 & 0.52 & 1.56 \\
LWW $(\mathrm{kg})$ & 1.67 & 0.08 & 33.45 & 0.84 & 1.83 \\
LW42(kg) & 2.72 & 0.64 & 36.37 & 1.00 & 7.80 \\
LW56 $(\mathrm{kg})$ & 3.88 & 1.11 & 48.65 & 1.05 & 9.00 \\
\hline
\end{tabular}

Means of the studied traits in table 2 are within the range reported by some authors elsewhere for different breeds of rabbits (Afifi et al 1989, El-Maghawry et al 1993, Iraqi (2008). The coefficient of variation (CV\%) ranged from 22.11 to $59.8 \%$ for the traits measured. This confirms that these traits in rabbits are subject to many effects such as genetic make up of the sires and non-genetic effects (year-season, parity and management of the herd). These are in agreement with the results of Odubote and Somade (1992); Ramadan (2005).

Results in table 3 shows the heritability $\left(\mathrm{h}^{2}\right)$ and repeatability $\left(\mathrm{R}^{2}\right)$ estimates for the traits measured.

Table 3. Estimates of heritability and repeatability of traits measured

\begin{tabular}{ccc}
\hline Traits & $\mathrm{h}^{2} \pm$ se & $\mathrm{R}^{2} \pm$ se \\
\hline LWB & $0.34 \pm 0.41$ & $0.034 \pm 0.24$ \\
LWW & $0.79 \pm 0.63$ & $-0.130 \pm 0.19$ \\
LW42 & $0.91 \pm 1.20$ & $0.003 \pm 0.24$ \\
LW56 & $0.62 \pm 0.54$ & $0.008 \pm 0.24$ \\
\hline
\end{tabular}

\section{Heritability}

The heritability estimates and their SE for the litters as presented in table 3 shows a medium to high value for all the traits measured which ranged from 0.34 to 0.91 . The same moderate to high estimates in litter traits had been reported by several authors (Khalil et al, 1987; Iraqi et al, 2006; Akanno and Ibe, 2005). This implies that these traits could be improved by combining pedigree and individual selection as the results shows that these traits were under the strong influence of additive genes and that individual selection would successfully improve them. Also, Njon and Nwakalor, 1998 obtained such high estimates in a mixed population of purebred and crossbred rabbits. Moreover, this finding is not in line with the findings of Iraqi (2008) who reported 0.00, 0.05 and 0.07 for litter weight at birth, $21 \mathrm{~d}$ and $28 \mathrm{~d}$ respec- 
tively. Iraqi suggested the improvement of litter traits of low heritability by selection based on predicted breeding values.

\section{Repeatability}

The repeatability estimates of the traits studied (table 3 ) shows low values, which ranged from -0.130 to 0.034 . This is not in line with the findings of Iraqi (2008) who reported 0.15 to 0.27 repeatability estimates of litter size traits in rabbits. Meanwhile most literature reported a range of 0.001 to 0.26 (Garcia et al 1982; Baselga et al 1992; Khalil 1994; Lukefahr and Hamilton 1997). Khalil (1994) and Iraqi and Youssef (2006) found that repeatability estimates for lactation traits were low and ranged from 0.002 to 0.189 . Because of low repeatability for most traits, it is very advantageous to consider more litters and parities before selecting a doe for these traits. Therefore selection of sires for these traits based on a single production record would not be efficient form a genetic standpoint and consequently assessment of several parities before selecting parents for these traits is necessary (Khalil and Mansour 1987 and Khalil 1994)

\section{Conclusions}

i. Since the estimates of heritability for traits of LWB, LWW, LW42 and LW56 are moderate to high, individual selection of parents in this population will lead to fast genetic progress in South Eastern Nigeria.

ii. Traits of LWB, LWW, LW42 and LW56 which showed low repeatability (ranges from -0.130 to 0.034 ) indicates that the certainty of repeating these traits in subsequent generation is not certain. This could be as a result of small population size as well as small parity and litter size. Therefore, repeatability estimates could be improved if the parity and litter size of the does in this population is increased.

\section{REFERENCES}

[1] Akanno E. C. and Ibe S. N. (2005). Estimates of genetic parameters for growth traits of domestic rabbits in the humid tropics. Nig. J Anim Prod. 17(7)

[2] Afifi E. A., Khalil M. H., and Emara, M. E. (1989). Effects of maternal performance and litter preweaning traits in doe rabbits. Journal of Animal Breeding and Genetics. 106: 358-362

[3] Baselga M, Gomez E, Cifre P and Camacho J (1992). Genetic diversity of litter size traits between parities in rabbits. In: Proc. $5^{\text {th }}$ World Rabbit Congr., Oregon State Univ., Corvallis, July 1992, Vol A 198-205

[4] Becker W. A. (1984). Manual of Quantitative Genetics. Academic Enterprises, Pulman Washington

[5] Bolet G, Esparbie J and Falieees J. (1996). Relations entre nombre de foetus par corne uterine, la taille de portee a la naissance et la croissance ponderale des lapereaux. Annales de Zootechnie 45:186-200 http://animres.edpsciences.org/index.php?option=article\&ac cess $=$ standard\&Itemid $=129 \& u r l=/$ articles/animres $/$ pdf $/ 1996 /$ 02/Ann.Zootech._0003-424X_1996_45_2_ART0007.pdf

[6] Chineke C. A and Raheem, M. A. (2009). Heritability Estimates of Rabbit litter and linear body traits at pre and post weaning in the Humid Tropics. Proceedings of the $34^{\text {th }}$ Annual Conference of the NSAP, March 16 - 19 2009, Uyo Nigeria

[7] Chen, C. P., Rao, D. R., Sunki, G. R. and Johnson W. M. (1978). Effect of weaning and slaughter ages upon rabbit meat production. I. Body weight, feed efficiency and mortality. J. Anim. Sci. 46 (3); $573-577$

[8] El-Maghawry A. M, Soliman A. M. and Khalil H. H. (1993). Doe milk production as affected by some genetic and environmental factors in New Zealand White and Californian rabbits under the Egyptian conditions. Egyptian Journal of Rabbit Science 3 (2): 141-150

[9] Fielding, D and Matheron G. (1991). The Tropical Agriculturist (Rabbits) $1^{\text {st }}$ Ed. 1-3

[10] Graybill, F. A. and W. H. Robertson (1957). Calculating confidence intervals for genetic heritability. Poult. Sci. 36: 261-265

[11] Garcia F, Baslega M, Blasco A and Deltoro J (1982) Genetic analysis of some productive traits in meat rabbits. I. Numeric traits. In: Proc $2^{\text {nd }}$ World Congress on Genetics Applied to Livestock Production, Madrid, Spain, October 1982, Vol 7: 557-562

[12] Iraqi M. M. (2008) Estimation of heritability and repeatability for maternal and milk production traits in New Zealand White rabbits raised in hot climate conditions. Livestock Research for Rural Development 20(8)

[13] Iraqi M. M.; Ibrahim M. K.; Hassan N. S. H.; El Deghadi A. S. (2006). Evaluation of litter traits in purebred and crossbred rabbits raised under Egyptian condition. Livestock Research for Rural Development 18(6)

[14] Iraqi M. M. and Youssef Y. M. K. (2006). Genetic analysis of milk production traits in New Zealand White rabbits raised in Egypt. Egyptian Journal of Rabbit Science 16(1): 1-13

[15] Khalil M. H; Owen J. B; Afifi E. A. (1987). A genetic analysis of litter traits in Bauscat and Giza white rabbits. Animal Production 45: 123 - 134

[16] Khalil M. H. (1994). Lactational performance of Giza White rabbits and its relation with pre-weaning litter traits. Animal Production 59(1): 141-145

[17] Khalil M. H and Mansour H. (1987). Factors affecting reproductive performance of female rabbits. Journal of Applied Rabbit Research 10: 140-145

[18] Lebas F, Coudert P, Rouvier, R; De Rochambeau H. (1986). The Rabbit Husbandry, Health and Production. FAO, United Nations Publications divisions, Termedi, Caracilla, 00100, Rome, Italy

[19] Lukefar S. D. and Hamilton H. H. (1997). Heritability and repeatability estimates of maternal performance traits in purebred and crossbred does. World Rabbit Science 5(3): 99-105

[20] Njon M. N. and Nwakalor L. N. (1998). Estimates of genetic parameters in a mixed population of pure and crossbred rab- 
bits. Proceedings of Silver Anniversary Conference of the Nigerian Society for Animal Production, March 21 - 26, 1998; Abeokuta, Nigeria

[21] Odubote I. K. and Somade B. (1992). Genetic analysis of rabbit litter trait at birth and weaning. Nigerian Journal of Animal Production 19: 64 - 69.

[22] Pascual J. J., Cervera C, Blas E and Fernandez-Carmona J. (1996). Milk yield and composition in rabbit does using high fat diets. $6^{\text {th }}$ World rabbit congress, Toulouse, France, 1: 259-262
[23] Petersen .J, Hartmann .J and Mennicken L. (1996) Effects of prenatal on postnatal performance of does. $6^{\text {th }}$ World rabbit Congress, Toulouse, France, 9-12 July. Volume 2:103-106

[24] Ramadan S. I .A. (2005). A study on the performance of rabbit doe for some litters, reproduction and milk production traits. M. Sc. Thesis, Faculty of Veterinary Medicine, Banha University, Egypt 